Research/Technical Note

\title{
Comparing Yield Performance and Morpho-agronomic Characters of Landraces and Released Varieties of Field Pea (Pisumsativum L.) at Agarfa and Goro Woredas, Bale Zone, Oromia Region, Ethiopia
}

\author{
Benti Ofga \\ Department of Biology, Ethiopian Biodiversity Institute Goba Biodiversity Center, Goba, Ethiopia \\ Email address: \\ bentiofga@gmail.com
}

To cite this article:

Benti Ofga. Comparing Yield Performance and Morpho-agronomic Characters of Landraces and Released Varieties of Field Pea (Pisumsativum L.) at Agarfa and Goro Woredas, Bale Zone, Oromia Region, Ethiopia. International Journal of Genetics and Genomics. Vol. 7, No. 3, 2019, pp. 34-49. doi: 10.11648/j.ijgg.20190703.11

Received: April 5, 2019; Accepted: June 1, 2019; Published: July 26, 2019

\begin{abstract}
Sixteen Field Pea varieties (8 of them farmers' varieties and 8 of them improved varieties) were tested to compare yield performance and morpho-agronomic characters among the traits on the seed yield. The genotypes were grown in Randomized complete block design at Goro and Agarfa community seed bank in 2017/18. Analysis of variance revealed that there were highly significant differences among the genotypes for most of the traits at individual and across locations. From the combined analysis of variance, significant $(\mathrm{p} \leq 0.05)$ effect due to location, varieties and $\mathrm{G} \times \mathrm{E}$ was observed for most of the traits. The varieties showed wider variability in mean seed yield of 833.33 - 2083.33 kg ha-1, 1250--3750 kg ha-1 and 833.33 - 3750 at Goro, Agarfa and across location, respectively. PCV was higher than the genotypic coefficients of variation (GCV) in most of the traits. The highest phenotypic coefficient variances (PCV) were found for days to flowering (95\%), while lowest PCV was recorded for days to maturity $(6.6 \%)$. The result from combined analysis indicated that high heritability values $(>70 \%)$ were recorded for characters considered such as days to flower initiation and days to maturity which indicates that these traits are more governed by genetic variance than environmental. Seed yield showed significant $(\mathrm{p} \leq 0.01)$ positive phenotypic correlations with hundred seed weight, above ground biomass, harvest index and plant height at each location. Similarly, significant $(\mathrm{p} \leq 0.01)$ positive and negative phenotypic and genotypic correlations between the yield components were observed at each location. The highest seed yield was recorded in 32038 variety (30.83kunt/hect and the lowest seed yield was recorded in 32039 variety $(22.91 \mathrm{kunt} / \mathrm{hect})$ from farmers varieties at Agarfa location. In Goro the highest seed yield was recorded in 32039 variety $(18.75 \mathrm{kunt} /$ hect and the lowest seed yield was recorded in Orome variety $(9.38 \mathrm{kunt} / \mathrm{hect})$ from farmers varieties. Generally, it has been observed the presence of variability among the genotypes, heritability and relationships in the tested traits of the genotypes studied.
\end{abstract}

Keywords: Heritability, Genetic Advance, Correlation, Grain Yield, Farmers' Varieties, Improved Varieties

\section{Introduction}

Field pea (Pisumsativum L.) is an annual herbaceous legume belonging to the family Fabaceae that adapted to cool moist climate with moderate temperature. It is the second most important stable cool-season food legume among the highland pulses in rural Ethiopia. Field pea produced in various regions and widely grown in north, south, west and central parts of the country including, pocket areas in highlands and mid highlands with altitude ranging from 1800-3000 m.a.s.l. Center of origin/diversity of field pea are East Africa and West Asia with secondary center in South Asia and South and East Mediterranean sub-regions 1]. The species $P$. sativumis dominant in Ethiopia even though wild and primitive forms are also known to exist in the high elevation of the country [2].

Field pea with other food legumes covers about $11.54 \%$ of the total 1.3 million hectares of crop areas in Ethiopia and is 
the 3rd most important stable food legume among the highland pulses in rural Ethiopia [3]. This crop is very much important in the highlands of Bale, South Eastern Ethiopia since it fetches cash for the farming community and also serves as rotational crop which play great role in controlling disease epidemics in areas were cereal mono cropping is abundant. It also plays a significant role in soil fertility restoration as a suitable rotation crop that fixes atmospheric nitrogen and good source of cash to farmers and foreign currency to the country [4].

Generally, it is a crop of manifold merits in the economic lives of the farming communities of high lands of Ethiopia. It is a rich source of protein $(25 \%)$, carbohydrate $(12 \%) \mathrm{s}$, vitamins $\mathrm{A}$ and $\mathrm{C}$, calcium and phosphorus, apart from having a small quantity of iron. Peas being very rich in proteins are valuable for vegetable purposes. Even though the above facts clearly show the important role the crop plays in the country's agriculture, its average seed yield has remained very low in the highlands of Bale, Ethiopia [5]. According to a study [6] field pea covers about $214,253.07$ ha of the total arable land with a total production of 2,752,981.27 Quintals. This constitutes about $12.85 \%$ of the total area covered by pulses and $12.43 \%$ of the total annual production of pulses in the country. The major reasons are: susceptibility of the landraces to array of diseases, inherently low yield potential of the landraces and poor management practices. Diseases, particularly, Ascochyta blight (Ascochytapisi), Powdery and downy mildew (Erysiphepolygoni) are the major constraints, causing substantial yield loss and instability in yield [7]. Powdery mildew and Ascochyta blight has been reported to be the major field pea disease in the mid altitudes and may reduce yield by $20-30 \%$ under moderate severity. It also indicated that when the disease is severe, susceptible lines could be killed and in particular, cause severe damage to local landraces in Bale highlands. It is planted in rotation with barley and wheat.

Field pea grows twice a year during "belg" (March to July) and "meher" (July to December). Grain harvest by small farmers falls between 4-6 and 2-3 t/ha in belg and meher seasons respectively around Sinana. Aphids, low yielding a local varieties, lodging, diseases (powdery and downy mildew), and pod shattering are the major production constraints to field pea production in Bale in that order of importance. Dadimos and Tullushenen are new field pea cultivars adapted to the southeastern highlands of Ethiopia, developed by Sinana Agricultural Research Center through its regional breeding program. They are high yielding and medium maturing (140-145 days) with high protein content. susceptible lines could be killed and in particular, cause severe damage to local landraces in Bale [8].

Traditionally, plant breeders have optimized yield largely by empirical selection with little regard for the physiological processes involved in yield increase. More recently, focused on optimize yield in pea have focused on the physiological mechanisms involved in the seed setting and fruit filling However, selection of high yielding cultivars via specific traits requires knowledge of not only final yield but also the many compensation mechanisms among yield components resulting from changing genotypic, environmental and management factors. Grain yield of pea is a quantitative trait which is affected by many genetic and environmental factors [9].

Genetic variability is an essential prerequisite for crop improvement program for obtaining high yielding varieties. On the other hand, yield is a complex character and is associated with some yield contributing characters. The understanding of association of characters is of prime importance in developing an efficient breeding program. The correlation studies provide information about association between any two characters. The path coefficient analysis provides the partitioning of correlation coefficients into direct and indirect effects giving the relative importance of each of the causal factors [10]. Despite the importance of such investigation and much works done to improve the production and productivity of this crop, but there is no sufficient work has been done regarding landraces for understanding and describing the nature and extent of GCV, PCV, heritability in broad sense, genetic advance, association among yield and yield related traits and yield performance of field pea varieties developed for south east high land Ethiopia Therefore, this work has been designed with the following objectives:

\subsection{General Objective}

The general objective of the present study is:

Comparing Yield Performance and Morpho-agronomic Characters of Landraces with Released Varieties of Field Pea (Pisumsativum L.) at Agarfa and Goro Woredas, Bale Zone, Oromia Region, Ethiopia.

\subsection{Specific Objectives}

1. To estimate the genetic variability, heritability and genetic advance of different pea genotypes.

2. To compare yield product performance selected landraces and released varieties of field pea genotypes.

3. To assess the extent of association among agronomic characters of field peagenotypes.

\section{Materials and Methods}

\subsection{Description of the Study Site}

The study was conducted in Oromia regional state, Bale Zone Agarfa and Goro Woredas. Agarfa Community Gene Bank, which is located $457 \mathrm{~km}$ South East of Addis Ababa. The average annual mean temperature, is $18^{\circ} \mathrm{C} \& 22^{\circ} \mathrm{C}$, night and day respectively. The geographic location of Agarfa community seed bank is $8^{\circ} 32$ ' 32 " $\mathrm{N}$ longitudes and $39^{0} 14^{\prime} 03$ ' $E$ latitude with an elevation of 2460 meters above sea level. The center represents high lands of Bale with average annual rainfall of $850-2000 \mathrm{~mm}$. The dominant soil type is black and slightly acidic.

Gorowareda Chafe Mana Community Gene Bank, which was located $487 \mathrm{~km}$ South East of Addis Ababa. The average 
annual mean temperature, is $18^{\circ} \mathrm{C} \& 24^{\circ} \mathrm{C}$, night and day respectively. The geographic location of ChefeMana is $77^{\circ} 56^{\prime} 25^{\prime} \mathrm{N}$ longitudes and $65^{\circ} 37^{\prime} 75^{\prime \prime} \mathrm{E}$ latitude with an elevation of 2034 masl. The center represents high lands of Bale with average annual rainfall of $700-1560 \mathrm{~mm}$. The dominant soil type is brown and slightly acidic.

\subsection{Experimental Material}

16 field pea varieties was used. Out of these 8 of them farmer's varieties and 8 of them were released varieties. The source of different field pea varieties were be SARC and EBI Gene bank and planted in 2017 main summer season for study. The descriptions of field pea genotypes used in the study are listed in table 1 below.

Table 1. Description of Released and farmers varieties of Field peain Ethiopia was used in the Study.

\begin{tabular}{lll}
\hline No. & Accessions names & Farmers varieties/Released \\
\hline 1 & Orome & EBI \\
2 & 32039 & EBI \\
3 & 231282 & EBI \\
4 & 231284 & EBI \\
5 & 230665 & EBI \\
6 & 32038 & EBI \\
7 & 320339 & EBI \\
8 & 320337 & EBI \\
9 & FP-Tulu Shenen & SARC \\
10 & FP-Hursa & SARC \\
11 & FP-Weyib & SARC 2017 New \\
12 & FP-Wayitu & SARC \\
13 & FP-Bamo & SARC \\
14 & FP-Harena & SARC \\
15 & FP-Urji & SARC \\
16 & FP-Hortu & SARC 2017 New \\
\hline
\end{tabular}

\subsection{Experimental Design and Trial Management}

The experiment was conducted using Randomized Complete Block Design (RCBD) with two replications of four blocks per replications and four treatments per block as given by Cochran and Cox (1957). Each plot were consisted of four rows of $3 \mathrm{~m}$ length $\mathrm{x} 1.6 \mathrm{~m}$ width with spacing $40 \mathrm{~cm}$ between rows and $10 \mathrm{~cm}$ between plants. The space between plots within block is $1.5 \mathrm{~m}$ between blocks within each replication as well as between replications was $1 \mathrm{~m}$. Each rows were contained 30 plants and each plot consist of total of 120 plants. Data collected from five randomly selected plants of each genotype from each replication for 12 quantitative characters from two central rows. Natural fertilizer (compost) was applied at the rate of 20Qt/ha before one week of planting. Seedling is done at rate of $100 \mathrm{~kg} / \mathrm{ha}$ is applied. Seed and natural fertilizer was drilled uniformly by hand. Standard agronomic practices was followed and neither herbicides nor insecticides are applied.

\subsection{Data Collected}

Data on quantities and qualitative was collected either on the plot bases or from four central rows randomly selected plants of wheat genotypes on the following characters.

1. Plant height $(\mathrm{PH})$ : the height measured in $\mathrm{cm}$ from the ground level to the top of the plant.

2. Number of pods per plant (NPP) - the total number of healthy pods recorded at physiological maturity from five randomly selected plants.

3. Pod length (PL): the average length of the longest pod expressed in $\mathrm{cm}$ at physiological maturity from five randomly selected plants per plant.

4. Seeds number per pods (SNPP): the number of seeds were counted for each podof the five sample plants and averaged over the number of pods.

5. Day to emergence (DE): day to emergence was recorded when $50 \%$ of the plant in each plot emerged out.

6. Day to flowering (DF): day to flowering was recorded when $50 \%$ of the plant population in each plot produce flowers.

7. Day to flower initiation (DFI): The days from the date of sowing to the date at which the first bud appears per plots.

8. Day tomaturity (DM): recorded as the day from emergence to maturity when $50 \%$ of the plant population per plot have turned yellowish or showed sign of senescence.

9. Yield per plot (YPP) (kg): The ratio of grain yield in $\mathrm{k} /$ gram per plot.

10.100 seeds weight: the weight of 100 seeds selected randomly from five plants per Plots.

11. Above ground Biomass Weight per plot (AGBPP in $\mathrm{kg} / \mathrm{m} 2$ ): Whole above ground plant parts on the plot harvested, sun dried and weighted from each plot. This value again converted to $\mathrm{kg}$ hectare.

12. Harvest index (HI): calculated by the following formula:

$$
\text { Harvest Index }(\mathrm{HI})=\frac{\text { seed yield per plot }(\mathrm{kg})}{\text { Biomass per plot }(\mathrm{kg})}
$$

\section{Result and Discussions}

\subsection{Quantitative Characters}

The minimum, maximum and mean values for 12 characters are showed in Table 2 and 3 for Agarfa and Goro, respectively. Wide ranges were recorded for most of the Character studied both at and Goro Variety Orome had minimum values for days to flowering initiation (39days) days to flowering (46) and days of maturity (88), and plant height (84.6) at Agarfa and minimum values for days to flowering initiation (44 days) days to flowering (50) and days of maturity (70), and plant height (88) at Goro while variety wayib had the least values for days to emergence (7) and (9) at Goro and Agarfa respectively. 100 Seed weight (14g) and harvest index $(0.5 \%)$ were minimum values recorded whereas days to flowering initiation (44 days) days to flowering (50) and days of maturity (70), plant height (88) and pod length were maximum values recorded at Goro 
while accession 231282 was observed to have the highest values for 100SW and Yield per plot at Agarfa with 21g and 7.8grespectively.

Minimum yield per Plot $(0.4 \mathrm{~kg})$ pod per plant $(8.2 \mathrm{~g})$ and aboveground biomass $(0.7 \mathrm{~g})$ values were recorded for Harana variety at Goro. From released varieties urji, recorded maximum value for days to flowering initiation (64 days) days to flowering (68) and days of maturity (136) at Agarfa. These results were in harmony with reports that noted wide range of variations in seed yield per plant, per plot and harvest index [11]. Consistent with the results of this study reported that the Mean value of days to flowering, days to maturity, plant heights and number of pod per plant were $60.129,153,177,38$, respectively [12]. As result reported [13] Days to emergence (DTE) mean value ranged from 7-9 days, Days to flowering (DTF) stretched from 42 to 72 days, Grain filling period (GF) from 4471, Pod per plant (ppp) from 3 to 30 and Seed per pod from 2-6 per plot. Days to maturity (DTM) ranged from 85-134.

Table 2. Minimum and Maximum scoring genotypes and Mean values for the 12 character of the 16 Field pea genotypes evaluated at Agarfa.

\begin{tabular}{|c|c|c|c|c|c|c|c|c|}
\hline \multirow{2}{*}{ Characters } & \multicolumn{2}{|l|}{ Maximum } & \multicolumn{2}{|c|}{ Minimum } & \multirow{2}{*}{ Mean } & \multirow{2}{*}{ Variance } & \multirow{2}{*}{$\mathbf{S D}( \pm)$} & \multirow{2}{*}{ LSD } \\
\hline & Value & Genotypes & Value & Genotypes & & & & \\
\hline Days to emergence & 12 & 320339 & 9 & Wayib & 10.4 & 2.268 & 1.50 & 0.78 \\
\hline Days Flower Initiation & 64 & Urji & 39 & Orome & 53.3 & 116.130 & 10.77 & 3.48 \\
\hline Days of Flowering & 68 & Urji & 46 & Orome & 60.21 & 122.205 & 11.05 & 4.1 \\
\hline Days of Maturity & 136 & Urji & 88 & Orome & 129.93 & 128.196 & 11.32 & 2.09 \\
\hline Plant Height(cm) & 210 & Hortu & 84.6 & Orome & 156.7 & 1799.47 & 42.42 & 14.5 \\
\hline Pod number Per Plant & 60.6 & Wayitu & 18.2 & Harana & 38.68 & 167.403 & 12.93 & 7.21 \\
\hline Seed per Pod & 7.6 & Wayib & 4.8 & Tulu shenan & 6.01 & 0.357 & 0.598 & 0.3 \\
\hline Seed Yield per plot(kg) & 1.8 & 231282 & 0.6 & Harana & 1.25 & 0.152 & 0.390 & 1.38 \\
\hline HundredSeedWeight(g) & 21 & 231282 & 13 & 32038 & 16.43 & 4.702 & 2.16 & 0.2 \\
\hline Above groundBiomass $(\mathrm{g})$ & 5.1 & 320337 & 1.8 & Harana & 3.48 & 1.599 & 1.26 & 0.69 \\
\hline Harvest index $(\mathrm{g})$ & 77.78 & 32038 & 20 & Bamo & 37.84 & 241.07 & 15.52 & 9.5 \\
\hline
\end{tabular}

Table 3. Minimum and Maximum scoring genotypes and Mean values for the 12 character of the 16 Field pea genotypes evaluated at Goro.

\begin{tabular}{|c|c|c|c|c|c|c|c|c|}
\hline \multirow{2}{*}{ Characters } & \multicolumn{2}{|c|}{ Maximum } & \multicolumn{2}{|c|}{ Minimum } & \multirow{2}{*}{ Mean } & \multirow{2}{*}{ Variance } & \multirow{2}{*}{$\mathbf{S D}( \pm)$} & \multirow{2}{*}{ LSD } \\
\hline & Value & Genotypes & Value & Genotypes & & & & \\
\hline Days to emergence & 7 & Wayib & 10 & 320337 & 8.03 & 0.92 & 0.96 & 0.34 \\
\hline Days Flower Initiation & 44 & Orome & 70 & Bamo & 68.9 & 82.26 & 9.07 & 3.81 \\
\hline Days of Flowering & 50 & Orome & 79 & Bamo & 7.12 & 6130.9 & 78.34 & 3.81 \\
\hline Days of Maturity & 70 & Orome & 89 & Bamo & 111.6 & 52.27 & 7.23 & 1.98 \\
\hline Plant Height(cm) & 88 & Orome & 119 & Bamo & 91.8 & 264 & 16.25 & 10.9 \\
\hline Pod number Per Plant & 8.2 & Harana & 34.8 & 231282 & 18.8 & 23.04 & 4.8 & 3.61 \\
\hline Pod length $(\mathrm{cm})$ & 4.6 & Wayib & 6.6 & Bamo & 5.5 & 0.24 & 0.49 & 0.32 \\
\hline Seed per Pod & 4.2 & Tulushana & 6.6 & 32039 & 5.75 & 0.29 & 0.54 & 0.36 \\
\hline Seed Yield per plot(kg) & 0.4 & Harana & 1.0 & 32039 & 0.6 & 0.026 & 0.16 & 0.08 \\
\hline HundredSeedWeight(g) & 14 & Bamo & 23 & 231282 & 17.8 & 5.1 & 2.26 & 1.67 \\
\hline Above groundBiomass(g) & 0.7 & Harana & 3.3 & 320339 & 1.34 & 0.24 & 0.49 & 0.33 \\
\hline Harvest index(g) & 0.5 & Bamo & 60 & Orome & 41.8 & 306.25 & 17.5 & 12.2 \\
\hline
\end{tabular}

\subsection{Analysis of Variance}

The analysis of variance for the 12 characters studied at Agarfa and Goro are presented in Table 4. Analysis of variance for the characters tested combined over locations using RCBD design is presented in Table 5. Both at Agarfa and Goro highly significant $(\mathrm{P}<0.01)$ genotypic difference were observed among the genotypes for all characters considered Table 4 . The significance of genotype difference indicates the presence of variability for each of the characters among the tested entries.

Genetic variability is a prerequisite for any crop improvement programs. Several variability studies have been carried out for various pulse crops such as faba bean, Field pea species [14-17]. Phenotypic and genotypic coefficients of variation and heritability were commonly used genetic parameters. Information on correlation of characters was also used as crucial for indirect selection for improvement of complex character like seed yield. This investigation was carried out to assess the genetic variability of 16 Field pea varieties for 12 morphological characters.

After combined analysis, highly significant $(\mathrm{P}<0.01)$ location effect for days to emergence, days to flowering, days to flower initiation, days to maturity, number of pod per plant, plant height, yield per plot while 100 seed weight, seed per pod and pod length had significant location effect indicating the phenotypic expression of these characters were different at the two locations Table 5. Genotype effects was highly significant for days to maturity while the rest were significant for all traits except above ground biomass and Harvest index. The Mean square due to genotype $(\mathrm{G}) \mathrm{x}$ location (L) interaction was highly significant for days to maturity and days to flowering initiation and days to flowering while pod per plant, pod length, seed per pod, yield per plot,100 seed weight and plant height significant, this indicate that differential response of genotypes for these character at each 
location. Because of significant genotype by environmental interaction for most of the characters, the analysis of variance and other estimates were done location-wise, as well as combined analysis for few variances. Similarly result was reported by [18] mean squares due to location were highly significant for all traits indicating that there are differences between the two environments, which are significant enough to see the genetic performance of field pea germplasm. It is evident from the results that mean squares due to genotypes were highly significant for thousand seed weight and seed yield, whereas, non significant for pod per plant as well as seed contributing traits, indicating the existence of sufficient genetic variability among the tested genotypes. Mean squares due to the interaction between location and genotype were highly significant for all temporal data and seed yield whereas non significant for the rest of the traits. The field pea accessions in this study showed significant phenotypic variability in terms of phenology and yield attributes [19].

Table 4. Analysis of variance (Mean squares) for the 12 characters of 16 Field pea genotypes grown evaluated.

\begin{tabular}{|c|c|c|c|c|c|c|c|}
\hline \multirow[b]{2}{*}{ Characters } & \multicolumn{4}{|c|}{ Agarfa Location } & \multicolumn{3}{|c|}{ Goro Location } \\
\hline & $\begin{array}{l}\text { Replication } \\
(\mathbf{d f}=\mathbf{1})\end{array}$ & $\begin{array}{l}\text { Genotypes } \\
(\mathrm{df}=16)\end{array}$ & $\operatorname{Error}(d f=15)$ & Replication $(\mathrm{df}=1)$ & $\begin{array}{l}\text { Genotypes } \\
(\mathrm{df}=16)\end{array}$ & $\operatorname{Error}(d f=15)$ & CV $(\%)$ \\
\hline Days to emergence & 0.031 & 0.48 & 0.109 & $11.28^{*}$ & $0.96 * *$ & 0.22 & 5.76 \\
\hline Days of Flowering & $81.28 * *$ & $22.66 * *$ & 29.74 & $215.3 * *$ & $64.9 * *$ & 25.7 & 6.45 \\
\hline Days of Maturity & $6.12 *$ & $65.72 * *$ & 7.72 & 1.5 & $101.04 *$ & 6.9 & 2.36 \\
\hline Plant Height(cm) & $1874.12 * *$ & $803.12 * *$ & 374.3 & $1149.6^{* *}$ & $259 * *$ & 210 & 15.78 \\
\hline Pod length $(\mathrm{cm})$ & $0.78 * *$ & $0.48 * *$ & 0.069 & $0.08 * *$ & $0.36 * *$ & 0.19 & 7.9 \\
\hline Seed Yield per Pod(g) & $5.2 * *$ & $0.315^{*}$ & 0.16 & 1.13 & $0.24 * *$ & 0.23 & 8.38 \\
\hline Seed Yield per plot(g) & 0.054 & $0.195 * *$ & 0.076 & $0.05 * *$ & $0.037 * *$ & 0.012 & 18.8 \\
\hline Hundred Seed Weight(g) & $0.5 * *$ & 3.79 & 3.36 & 1.53 & $5.6^{* *}$ & 4.9 & 12.5 \\
\hline AbovegroundBiomass(g) & 0.46 & $1.20 * *$ & 0.86 & $0.45 * *$ & $0.26 * *$ & 0.21 & 33.3 \\
\hline Harvest index $(\mathrm{g})$ & $153.28 * *$ & $770.6 * *$ & 159.6 & $1918 * *$ & $285.5 * *$ & 262.3 & 38.8 \\
\hline
\end{tabular}

$* *$ and $*$ Significant at $1 \%$ and $5 \%$ probability level respectively $\mathrm{df}=$ degree of freedom, $\mathrm{CV}=$ Coefficient of Variance, $\mathrm{G}=\mathrm{Genotype}$.

Table 5. Combined analysis of variance (Mean squares) for 12 traits of 16 field pea genotypes grown at Agarfaand Goro.

\begin{tabular}{|c|c|c|c|c|c|c|c|}
\hline Characters & $\begin{array}{l}\text { Replication within } \\
\text { location }(\mathrm{df}=1)\end{array}$ & Locations $(d f=1)$ & $\operatorname{GxL}(d f=15)$ & $\operatorname{Error}(d f=31)$ & CV $(\%)$ & LSD & $\begin{array}{l}\text { Genotype(G) } \\
(\mathrm{df}=15)\end{array}$ \\
\hline Days to emergence & $5.06 * *$ & $90.25^{*}$ & 4.8 & 0.81 & 9.8 & 0.54 & $2.63 * *$ \\
\hline Days Flower Initiation & $0.76^{*}$ & $3890.6^{*}$ & $60.7 *$ & 36. & 9.8 & 3.9 & $141.9 * *$ \\
\hline Days of Flowering & $16.0^{*}$ & $5256.6^{*}$ & $43.3 *$ & 36.5 & 8.7 & 3.3 & $149.4 * *$ \\
\hline Days of Maturity & 0.76 & $5347.26^{*}$ & $47.19 *$ & 6.37 & 2.06 & 3.1 & $166^{*}$ \\
\hline Plant Height(cm) & 907.5 & $81011.4 *$ & $672.4 * *$ & 457.6 & 16.8 & 10.2 & $2209.4 * *$ \\
\hline Pod number Per Plant & 15.6 & $6320.25 *$ & $79.6 * *$ & 54.2 & 33.20 & 3.7 & $190.9 * *$ \\
\hline Seed Yield per Pod(g) & $3.33 * *$ & $1.05 * *$ & $0.31 * *$ & 0.28 & 9.14 & 0.21 & $0.34 * *$ \\
\hline Seed Yield per plot(g) & $0.16^{* *}$ & $6.63 *$ & $0.36^{* *}$ & 0.09 & 32.4 & 0.12 & $0.17 * *$ \\
\hline HundredSeed Weight(g) & 0.14 & $28.9 * *$ & $3.36 * *$ & 3.59 & 11.08 & 1.12 & $5.12 * *$ \\
\hline AbovegroundBiomass(g) & 0.1 & 72.7 & 2.3 & 0.9 & 40.2 & 0.37 & 1.81 \\
\hline Harvest index(g) & 128.3 & 228.8 & 228 & 215.9 & 36.8 & 8.6 & 250.7 \\
\hline
\end{tabular}

$* *$ and $*$ Significant at $1 \%$ and $5 \%$ probability level respectively $\mathrm{df}=$ degree of freedom, $\mathrm{CV}=\mathrm{Coefficient}$ of Variance, $\mathrm{G}=\mathrm{Genoty}$.

\subsection{Phenotypic and Genotypic Variations}

The amount of genotypic and phenotypic variability that exists in a species is essential in developing better varieties, via selection and breeding program. Variability is the addition of total hereditary effects from alarmed genes as well as the environment. Therefore, the variability is grouped into heritable and non-heritable components with suitable genetic parameters such as genotypic coefficient of variation (GCV), phenotypic coefficient of variation (PCV), heritability (h2) and genetic advance (GA). These genetic parameters help breeders in selection of suitable genotypes for genetic improvement of this crop. Estimated these variance components, studied are given in table 9 and 10 for Agarfa and Goro, respectively.

Phenotypic coefficient of variation (PCV) was found superior to the genotypic coefficient of variation $(\mathrm{GCV})$ for all the characters. High GCV along with high heritability and high genetic advance will give good information than each parameter [20, 21] Generally, the GCV values were lower than that of PCV for both locations. GCV at Agarfa were relatively higher than that of GCV values of these characters at Goro. The relatively slight differences between PCV and GCV for the rest of the character suggest less influence of the environmental factors. The study [22] reported high (GCV) for number of pods, number of branches, thousand seeds weight, plant height and days to flowers, while a study [23] reported high estimates of GCV for seed yield per plant, harvest index, number of pods per plant and plant height. This was full in agreement at both locations with the present study.

The genetic variance (GCV) took relatively much of the total variances for, days to flower initiation, secondary 
branch, thousand seed weight, above ground biomass, seed yield per plot, number of pods per plot, and harvest index. These effects were also detected from high heritability estimates for these characters (Table 10). On the other hand, relatively lower variance share of the total variance were observed for seed yield per plant, plant height, days to flower initiation and seed per plant, indicating the greater share of environmental variance in the total variability. The same result was reported [24] on plant height, number pod per plant, seed yield per plant, above ground biomass.

In the present study, at Agarfa, the highest genetic variance were observed for harvest index (8690.46) and plant height (615.96). While lowest genotypic variance were found for seed per pod (0.25), days to emergence (0.375), pod length $(0.445)$ above ground biomass (0.77), and the study [25] also reported wide genetic variations for harvest index and plant height.

The genotype variance at Agarfa was found to be relatively greater than its corresponding environment variance for days to flowering (65.41), days to flower emergence (0.375), days to maturity (61.86), plant height (615.96), pod per plant (97.4) and harvest index $(690.446 \mathrm{~kg})$. This implies that in the phenotypic expression of this character, the effect of environment factors is low. On the other hand the magnitude of genotypic variations were smaller than that of environmental variance at the same locations for number of 100 seed weight (2.11), days to flower initiation $(13.37 \mathrm{~g})$, seed yield per plot $(0.059 \mathrm{~kg})$, above ground biomass $(0.77 \mathrm{~kg})$ and pod length $(0.445 \mathrm{~g})$. This signifies the effect of environmental factors on the phenotypic expression of these traits were high.

At Goro, all the 12 characters studied showed a phenotypic variance greater than the genotypic variance (Table 7). At Goro, the genotypic variance is smaller than that of environmental variance except for days to emergence (0.37) days to flower initiation (56.2) and days to maturity (47.07) and in combined analysis, genotypic variances were higher than their environmental for all characters. This indicates that in the phenotypic variance the contribution of genotypic variance was high for all characters.

At Agarfa, the highest PCV was observed for harvest index
(77.07\%), number of pods per plant (35.54\%), above ground biomass $(36.7 \%)$, and seed yield per plant $(30.9 \%)$. The estimated PCV was low for days to emergence (7.3\%), days to maturity $(6.4 \%)$ and seed yield per pod (8.3). High genotypic coefficient of variation $(32.52 \%)$ and $(32.07 \%)$ were observed for Harvest index and number of seeds per pod, respectively. Whereas, the lowest value of genotypic coefficient of variation was estimated for days to maturity $(0.24 \%)$. Likewise phenotypic coefficient of variation was high for the number of seeds per pod (241.13\%) followed by (173.59\%). In Agarfa low GCV were observed for days to emergence (5.8), days to flower initiation (6.86), days to maturity (6.05), seed per pods (6.65) and 100seed weight (8.84) while highest GCV was recorded for harvest index (69.4). The result agree with the study [26].

At Goro, the highest GCV was recorded for days to flower $(62.0 \%)$ whereas the moderate genotypic coefficient variances $(\mathrm{GCV})$ were found for seed yield per plot (19\%), above ground biomass (11.8\%) and days to flower initiation $(10.8 \%)$. However, the lowest GCV were recorded for seed per pod (1.2\%) and 100 seed weight (3.3\%). The phenotypic coefficient variances (PCV) were found for days to flowering $(95 \%)$, harvest index (39.6\%), above ground biomass (36.6\%), seed yield per plot (26.6\%), pods number per plant (26\%), plant height (17\%) 100 seed weight (13\%) and days to flower initiation (13\%) while lowest PCV recorded seed per pods $(8.4 \%)$, pod length $(9.6 \%)$, days to emergence $(9.6 \%)$, days to maturity $(6.6 \%)$. The finding similar with that [27]. The study [28] estimated significant difference among genotype for all the characters except, pod bearing length, number of secondary branches per plant and number of seeds per pod. He reported high genotypic and phenotypic coefficient of variation for number of primary branches/plant, number of seeds/pod, 100 seed weight and seed yield/plant. The study [30] also reported PCV higher than the GCV for all the characters studied. The study [31] reported significant genotypic differences for all studied characters which included plant height, number of branches, number of pods/plant, pod length, number of seeds per pod in garden pea.

Table 6. Estimation of phenotypic ( $\sigma 2 p)$, genotypic $(\sigma 2 g)$ and environmental ( $\sigma 2 e)$ components ofvariances, phenotypic (PCV) and genotypic coefficients of variability $(G C V)$, broad sense heritability $(H)$, expected genotypic advance $(G A)$ and genetic advance as percent of the mean (GA\%) for 12 characters evaluated at Agarfa.

\begin{tabular}{|c|c|c|c|c|c|c|c|c|c|}
\hline Characters & MsTr & $\delta^{2} \mathrm{e}$ & $\overline{\delta^{2} g}$ & $\delta^{2} p$ & GCV & $\overline{P C V}$ & $h^{2}$ & $\overline{\text { GA }}$ & GA\% \\
\hline Days to emergence & 10.4 & 0.209 & 0.375 & 0.58 & 5.8 & 7.3 & 64.6 & 1.57 & 15 \\
\hline Days Flower Initiation & 53.3 & 21.35 & 13.37 & 34.72 & 6.86 & 11.05 & 38.5 & 4.2 & 7.8 \\
\hline Days of Flowering & 60.21 & 29.74 & 65.41 & 95.15 & 13.43 & 16.2 & 68.7 & 7.48 & 12.4 \\
\hline Days of Maturity & 129.93 & 7.72 & 61.86 & 69.58 & 6.05 & 6.4 & 88.9 & 10.9 & 8.39 \\
\hline Plant Height $(\mathrm{cm})$ & 156.7 & 374.3 & 615.96 & 990.27 & 15.83 & 20.08 & 62.2 & 35.7 & 22.8 \\
\hline Pod number Per Plant & 38.68 & 91.76 & 97.4 & 188.98 & 25.5 & 35.54 & 51.5 & 11.27 & 29.13 \\
\hline Pod length $(\mathrm{cm})$ & 5.78 & 0.069 & 0.445 & 0.51 & 11.54 & 12.35 & 87.2 & 0.61 & 10.6 \\
\hline Seed Yield per Pod(g) & 6.01 & 0.16 & 0.25 & 0.395 & 6.65 & 8.3 & 63.2 & 1.13 & 18.8 \\
\hline Seed Yield per plot(g) & 1.25 & 0.076 & 0.059 & 0.15 & 19.43 & 30.9 & 39.6 & 0.21 & 16.8 \\
\hline Hundred Seed Weight(g) & 16.43 & 3.36 & 2.11 & 5.47 & 8.84 & 14.23 & 38.6 & 1.47 & 8.9 \\
\hline AbovegroundBiomass(g) & 3.48 & 0.86 & 0.77 & 1.63 & 25.2 & 36.7 & 47.2 & 0.79 & 22.7 \\
\hline Harvest index(g) & 37.84 & 159.6 & 690.46 & 850.08 & 69.4 & 77.05 & 81.2 & 63.5 & 167.8 \\
\hline
\end{tabular}

$\mathrm{PCV}=$ Phenotypic coefficient variance, $\mathrm{GCV}=$ Genotypic coefficient variance, $\mathrm{GA}=$ Genetic Advance, and GA\% $=$ Genetic Advance as percent of Mean, $\sigma 2 \mathrm{p}$ $=$ Phenotypic variance, $\sigma 2 \mathrm{~g}=$ Genotypic variance, $\sigma 2 \mathrm{e}=$ Environmental variance, and $\sigma 2 \mathrm{gl}=$ Genotype and Location interaction variance. 
Table 7. Estimation of phenotypic $(\sigma 2 p)$, genotypic $(\sigma 2 g)$ and environmental $(\sigma 2 e)$ components of variances, phenotypic $(P C V)$ and genotypic coefficients of variability $(G C V)$, broad sense heritability $(H)$, expected genotypic advance $(G A)$ and genetic advance as percent of the mean (GA\%) for 12 characters evaluated at Goro.

\begin{tabular}{llllllllll}
\hline Characters & $\mathbf{M s T r}$ & $\boldsymbol{\delta}^{\mathbf{e}} \mathbf{s}$ & $\boldsymbol{\delta}^{\mathbf{2}} \mathbf{g}$ & $\boldsymbol{\delta}^{\mathbf{2}} \mathbf{p}$ & $\mathbf{G C V}$ & $\mathbf{P C V}$ & $\mathbf{h}^{\mathbf{2}}$ & $\mathbf{G A}$ & $\mathbf{G A} \%$ \\
\hline Days to emergence & 8.03 & 0.22 & 0.37 & 0.59 & 7.8 & 9.6 & 63 & 1.24 & 15.4 \\
Days Flower Initiation & 68.9 & 23.7 & 56.2 & 79.8 & 10.9 & 13 & 70 & 13.2 \\
Days of Flowering & 7.12 & 25.7 & 19.6 & 45.3 & 62.0 & 95 & 43 & 69.9 & 98 \\
Days of Maturity & 111.6 & 6.9 & 47.07 & 53.9 & 6.0 & 6.6 & 87 & 13 & 11.7 \\
Plant Height(cm) & 91.8 & 210 & 24.7 & 234.7 & 5.4 & 17 & 11 & 3.5 & 3.8 \\
Pod number Per Plant & 18.8 & 23 & 0.7 & 23.7 & 4.5 & 26 & 2.9 & 0.32 & 1.7 \\
Pod length(cm) & 5.5 & 0.19 & 0.085 & 0.28 & 5.3 & 9.6 & 30 & 0.3 & 5.5 \\
Seed Yield per Pod(g) & 5.75 & 0.23 & 0.005 & 0.24 & 1.2 & 8.4 & 2.1 & 0.23 & 4.1 \\
Seed Yield per plot(g) & 0.6 & 0.012 & 0.013 & 0.025 & 19.0 & 26.4 & 52.0 & 0.17 & 28.5 \\
Hundred Seed Weight(g) & 17.8 & 4.9 & 0.35 & 5.25 & 3.3 & 13.0 & 6.7 & 3.11 \\
AbovegroundBiomass(g) & 1.34 & 0.21 & 0.025 & 0.24 & 11.8 & 36.6 & 10.4 & 0.104 & 7.8 \\
Harvest index(g) & 41.8 & 262.3 & 11.8 & 273.5 & 8.2 & 39.6 & 4.3 & 1.6 & 3.7 \\
\hline
\end{tabular}

$\mathrm{PCV}=$ Phenotypic coefficient variance, $\mathrm{GCV}=$ Genotypic coefficient variance, $\mathrm{GA}=$ Genetic Advance, and GA\% $=$ Genetic Advance as percent of Mean, $\sigma 2 p$ $=$ Phenotypic variance, $\sigma 2 \mathrm{~g}=$ Genotypic variance, $\sigma 2 \mathrm{e}=$ Environmental variance, and $\sigma 2 \mathrm{gl}=$ Genotype and Location interaction variance.

Generally, the estimates for PCV were higher than GCV for the analogous character. This was in agreement with the finding [32] who reported high estimates of PCV than GCV for most of the characters. High genotypic and phenotypic variance estimates for the characters indicated that the germiplasm accessions under investigation possessed very high potential difference and this might be due to their genetic origin and differential adaptability. These results are further strengthened by finding [33] who reported that phenotypic variance and phenotypic coefficient of variation were higher than their consequent genotypic variance and genotypic coefficient variance

After combined analysis of variance of the 12 characters with homogenous error variance, except harvest index exhibited genotypic variance less than that of the environmental variance. While most of the characters had low genotypic $\mathrm{x}$ location interaction variance than environmental variance except for days to emergence and seed yield per pot. The larger environmental variance than genotypic variance signifies, in the phenotypic expression of that with larger environmental variance the contribution was greater which lead to high environmental impact in both location. The study [34] reported that similar result for Combined analysis of variance for some agronomic characters of field pea (Pisumsativum L.) genotypes/varieties were represented in Table 8 and there was highly significant $(\mathrm{P}<0.01)$ variation between days to flowering, days to maturity, pod per plant, seed per pod and plant height across locations indicating that the environmental factors was highly attributed for the variation. Furthermore, the result of combined analysis of variance for grain yield of 16 field pea genotypes tested across 2 environments showed that large environmental effects

Table 8. Phenotypic $\left(\delta^{2} p\right)$, Genotypic $\left(\delta^{2} g\right)$, Environmental variance $\left(\delta^{2} e\right)$ and Genotype $X$ Location interaction variance ( $\left.\delta^{2} g l\right)$ for 16 field pea genotypes from combined ANOVA over locations (Agarfa and Goro).

\begin{tabular}{|c|c|c|c|c|}
\hline Characters & $\delta^{2} \mathrm{e}$ & $\delta^{2} \mathrm{~g}$ & $\delta^{2} p$ & $\delta^{2} \mathrm{gl}$ \\
\hline Days to emergence & 0.81 & 44.7 & 45.5 & 1.99 \\
\hline Days Flower Initiation & 36. & 1927 & 1963 & 12.4 \\
\hline Days of Flowering & 36.5 & 2630 & 2666 & 3.4 \\
\hline Plant Height(cm) & 457.6 & 40276.9 & 40726.5 & 98.4 \\
\hline Pod number Per Plant & 54.2 & 3111.5 & 3208.8 & 12.7 \\
\hline Pod length $(\mathrm{cm})$ & 0.13 & 0.49 & 0.62 & 0.09 \\
\hline Seed per Pod(g) & 0.28 & 0.39 & 0.66 & 0.015 \\
\hline Seed Yield per plot(g) & 0.09 & 3.27 & 3.36 & 0.14 \\
\hline Hundred Seed Weight(g) & 3.5 & 12.65 & 16.25 & 0.9 \\
\hline Aboveground Biomass(g) & 0.9 & 35.86 & 36.84 & 0.7 \\
\hline Harvest index(g) & 215 & 6.45 & 222.25 & 6.5 \\
\hline
\end{tabular}

\subsection{Estimate of Heritability}

The estimated heritability for the studied characters at Agarfa and Goro are present in table 9 and 10 respectively. Heritability values are helpful in predicting the expected progress to be achieved through the process of selection [23]. Genetic coefficient of variation along with heritability estimate provides a reliable estimate of the amount of genetic to be expected through phenotypic selection [36]. Generally classified heritability estimates as low $(<50 \%)$, medium
(50-70\%) and high (>70\%). Based on this classification, at Agarfa the characters that had get highest heritability values are pod length $(87.2 \%)$, days to maturity (88.9) while seed per pods (63.2\%) Plant height (62.2) and day to flowering (68.7\%), pod per plant $(57.5 \%)$, harvest index $(53.5 \%)$ had medium heritability. However, seed yield per pod (39.6\%), days to flower initiation (38.8\%) and above ground biomass (47.2\%) and had low heritability values. The study [37] revealed that heritability estimates were high for plant height whereas, pod length and 100 seed weight exhibited 
moderately high heritability in pea which is similar with these finding. The study [38] observed high heritability for 100 seed weight, seed yield/plant, and number of seeds/plant in suggesting the pre dominance of additive gene action in the expression of these characters in field pea Hence, a good progress can be made if some of these characters are considered as selection criteria.

At Goro, the highest heritability values was recorded by days to maturity $(87 \%)$ and day to flower initiation $(70 \%)$ whereas, yield per plot (52\%), days to emergence $(63 \%)$ recorded medium results. Day to flowering (43\%) and the rest of characters were recorded low heritability. The lowest heritability was recorded by seed per pods (2.1\%). [1] reported results were contrast to the finding of high heritability was recorded for all characters viz.100-seed weight $(99.60 \%)$, plant height $(99.60 \%)$, seed yield/plant (98.50\%), days to maturity $(98.50 \%)$, days to $50 \%$ flowering $(96.90 \%)$, biological yield/plant $(96.40 \%)$, harvest index $(93.80 \%)$, number of pods/plant $(93.70 \%)$, pod length $(93.40 \%)$, and number of seeds/pod $(85.70 \%)$.

At both site, high heritability values $(>70 \%)$ were recorded for characters considered such as days to flower initiation and days to maturity which indicates that these traits are more governed by genetic variance than environment High estimate of heritability for characters viz. days to $50 \%$ flowering and seed yield/plant reported [39]. Similarly, high heritability (broad sense) estimates for days to maturity, plant height, number of branches/plant, number of pods/ plant, 100 seed weight, number of seeds per pod, harvest index and seed yield per plant in pea suggested [40]. High estimate of heritability for days to $50 \%$ flowering, days to maturity, plant height, number of pods/plant, pod length, harvest index and seed yield/plant and also reported moderate heritability for 100 -seed weight reported [41].

\subsection{Estimation of Expected Genetic Advance}

Genetic advance as percent of Mean measures the expected genetic progress that would result from selecting the best performing genotypes for a character being evaluated [42]. High heritability together with high genetic advance is vital tool for selection and for successful genetic improvement [43-44]. Selection based on this character with a relatively high genetic advance of the genotypes for the character. As shown in Table 8 for the study at Agarfa, genetic advance ranged from $(7.8 \%)$ for days of flower initiation to, (167.7\%) harvest index. There was relatively high genetic advance expressed as percentage of Mean for characters numbers of pods per plant, seed yield per plot, thousand seed weight, number of pods per plant and above ground biomass. These characters had relatively high GCV and PCV as well as moderate heritability. Low estimates of genetic advance expressed as percentage of Mean were observed for days to maturity, harvest index, seed yield per plant and plant height. Similarly high genetic advance as recorded for days to maturity and harvest index in Agarfa while the rest characters had low genetic advance.

At Goro, the range for genetic advance as present Mean was from $1.7 \%$ for pod per plant to $98 \%$ for days to flowering Table 9. The rest had relatively medium and low genetic advance expressed as percentage of Mean. Low estimates of genetic advance expressed as percentage of Mean were observed for plant height, pod length, seed yield per plant, and days to flowering. This study revealed that coupling of high heritability value with high genetic advance as percent of Mean for number of pods per plant, yield per plot and above ground biomass. Therefore, selection for these characters could help improve this crop if these characters are positively and strongly correlated with seed yield.

The low expected genetic advance at Goro for characters like days to flower initiation, number of pod per plant and seed yield per plant, had more than $50 \%$ heritability, is due to low variability for these character indicated by respective low GCV's and PCV's. This indicated the importance of genetic variability in improvement through selection. As observed in this study, the low expected genetic advance for seed yield per plant, number of secondary branch per plant and days to flower initiation was due to relatively low variability for this character. Therefore, even if heritability estimates provide basis for selection, genetic advance should always be considered simultaneously [45].

\subsection{Association Among Yield and Yield Components}

Estimates of genotypic and phenotypic correlation coefficients between each pair of characters were studied for studied locations (Table 9 and 10). In most cases, the phenotypic correlation coefficients were less in magnitude than the genotypic correlation coefficients that revealed the presence of inherent genetic relationships among various characters and less dependent on environment. In this study, at both locations genotypic correlation coefficients were found to be higher in magnitude than that of phenotypic correlation coefficients in most of the traits, which clearly indicated the presence of inherent association among various characters.

\subsubsection{Correlation of Yield with Yield Related Traits}

Phenotypic (rp) and genotypic ( $\mathrm{rg}$ ) correlation estimations between the various characters are present in Tables 9, 10 and 11 for Agarfa, Goro and for the combined dated of the two locations, respectively.

At both locations, phenotypic level of seed yield per plot was highly significantly and positively correlated with pods per plant, seed per pod and plant height. The present result is in accordance with the results reported [6] with regard to the correlations between seed yield per plot, plant height, seed per pod and pod per plant. Whereas thousand seed weight, days to emergence and harvest index were significant and positively correlated with this character at Agarfa, seed yield per plant at Goro. This result is in agreement with the study [46] assessed twenty F2 field pea and found significant differences among all the F2 plants for all the characters studied, except for days to emergence. pod length, plant height, number of pod/plant, 100 seed weight and were the major characters contributing to grain yield as these traits were significantly and positively 
associated with grain yield/plant.

At genotypic level, plant height, days to flower initiation, pod per plant and pod length at Agarfa and days to emergence, days to flowering, number of pods per plant, pod length and above ground biomass at Goro had highly significantly and positively correlated with seed yield per plot. Similarly, the study [47] conducted an experiment to study association among characters in field pea crosses in F4 generation and concluded that the characters like pod length, pods/plant, seeds/pod and harvest index recorded high positive and significant correlation with seed yield, suggesting their potential use in field pea improvement.

Days to flowering, days to maturity, 100 seed weight and harvest index at Agarfa and plant height, days to flower initiation, pod per plant and 100 seed weight at Goro significantly and positively correlated with this character. Days to flower initiation and seed per pods at Agarfa had significantly and negatively correlated with this character. Pod length and harvest index were significant and negatively correlated with seed yield per plot at Goro site, which synonym report with a study [48] studied 163 genotypes of pea including indigenous and exotic cultivars. Results indicated positive and significant association of seed yield/plant with biological yield/plant and pods/plant. Significant negative correlation of harvest index and pod length was observed with plant height.

In the combined analysis, the phenotypic and genotypic correlation of seed yield per plant had highly significantly and positively correlated with plant height, above ground biomass, seed yield per plant, 100 seed weight and number of pods per plant. This result implies that, as number of pod per plant and plant high increase, there will be high yield per plant and per plot. This result was reported [49]. At phenotypic and genotypic level, days to flower initiation and phenotypic level, days to maturity had significantly and negatively correlated with seed yield per plot. The result of positive correlation of days to flowering may be achieved at the expenses of 100 seed weight. Result of this character with seed had agreement with [50] and in agreement with the result of [51]. Whereas phonotypic level, days to flowering and genotypic level, above ground biomass and harvest index had highly significantly and negatively correlated with this character. In this study there was no significantly and positively correlation of character with seed yield per plot. This result implies that, as number of branch and plant high increase, there will be high yield per plant and per plot. This result was reported [52]. The negative and significant correlation between days to flowering, days to flower initiation is in harmony with the finding [53] in the Field pea.

\subsubsection{Estimates of Genotypic Csorrelation Coefficient Among the Others}

Days to emergence showed a highly significant and positive correlation with days to maturity $\left(\mathrm{rg}=0.687^{* *}\right)$, whereas above ground biomass $\left(\mathrm{rg}=-0.865^{* *}\right)$ and harvest index $\left(\mathrm{rg}=-0.616^{* *}\right)$ had highly significant and negative genotypic correlation with yield per plant. It implies that plant that early emerge may mature earlier and increase seed yield in field pea, which have positive and significant correlation with crop improvement. Similar result was reported by [16]. It also recorded significant and negative correlation with day to $50 \%$ flowering $\left(\mathrm{rg}=-0.85^{*}\right)$, day to flower initiation $\left(\mathrm{rg}=-0.168^{*}\right)$ and pod length $\left(\mathrm{rg}=-0.195^{*}\right)$ whereas, number of seeds per pod, plant height $(\mathrm{rg}=0.006)$ and 100 seed weight recorded positive but non-significant correlation with this trait. Days to flower initiation showed a highly significant and positive correlation with 100 seed weight $(\mathrm{rg}=0.62 * *)$ and yield per plant $\left(\mathrm{rg}=0.71^{* *}\right)$.

Table 9. Genotypic and phenotypic correlation coefficients among 12 characters of 16 field pea genotype studied at Agarfa.

\begin{tabular}{|c|c|c|c|c|c|c|c|c|c|c|c|c|}
\hline & DE & DI & DF & DM & PPP & SP & PL & PH & $100 S W$ & AGBM & HI & PY \\
\hline DE rp & 100000 & $0.393 * *$ & $0.799 * *$ & -0.443 & 0.093 & $-0.859 *$ & -.0 .329 & -0.455 & -0.336 & -0.234 & 0.136 & -0.248 \\
\hline $\mathrm{Rg}$ & & $0.573 * *$ & 0.127 & $0.896 * *$ & $0.956^{*}$ & 00.095 & $0.858 * *$ & $0.699 * *$ & $0.496 * *$ & $0.984 *$ & $0.577 * *$ & $0.856^{*}$ \\
\hline DI rp & & 100000 & $0.945 *$ & $0.383 * *$ & $0.775 *$ & -0.373 & 0.169 & $0.148 * *$ & -0.688 & -0.178 & -0.039 & $0.624 * *$ \\
\hline $\mathrm{Rg}$ & & & $0.347 * *$ & $0.759 *$ & 0.037 & $0.473 * *$ & $0.966^{*}$ & $0.675 * *$ & $0.899 * *$ & $0.923 *$ & $0.989 *$ & $-0.369 * *$ \\
\hline DF rp & & & 100000 & $0.359 * *$ & $0.573^{*}$ & -0.269 & $0.623 *$ & 0.568 & -0.533 & $-0.063 *$ & -0.188 & $0.868 *$ \\
\hline $\mathrm{Rg}$ & & & & $0.815^{* *}$ & 0.218 & $0.757 * *$ & $0.594 * *$ & $0.698 * *$ & $0.665^{* *}$ & $0.731 * *$ & $0.987 *$ & $0.473 * *$ \\
\hline DM rp & & & & 100000 & $0.957 *$ & $0.557 *$ & $0.859 * *$ & $0.484 * *$ & -0.305 & $0.585 * *$ & -0.357 & -0.690 \\
\hline $\mathrm{Rg}$ & & & & & $0.488 * *$ & 0.250 & 0.259 & $0.497 * *$ & $0.559 * *$ & 0.405 & 0.069 & $0.464 * *$ \\
\hline PPP rp & & & & & 100000 & $0.698 *$ & $-0.922 *$ & $0.477 * *$ & $0.398 * *$ & $0.518 * *$ & $-0.667 * *$ & $0.892 *$ \\
\hline $\mathrm{Rg}$ & & & & & & 0.205 & $0.615^{* *}$ & 0.357 & 0.215 & 0.028 & 0.495 & $0.812 *$ \\
\hline SP rp & & & & & & 100000 & $0.584 * *$ & 0.449 & $-0.986^{*}$ & $0.519 * *$ & $-0.948 * *$ & $0.988 *$ \\
\hline $\mathrm{Rg}$ & & & & & & & 0.065 & $0.872 * *$ & $0.769 *$ & $0.891 *$ & $0.480 * *$ & 0.293 \\
\hline PL rp & & & & & & & 100000 & $0.747 * *$ & -0.244 & $0.897 *$ & -0.298 & $-0.223 * *$ \\
\hline $\mathrm{Rg}$ & & & & & & & & 0.287 & 0.279 & $0.458 * *$ & 0.097 & $0.541 *$ \\
\hline PH rp & & & & & & & & 100000 & $-0.594 * *$ & $0.569 * *$ & $-0.466 * *$ & $0.998 *$ \\
\hline $\mathrm{Rg}$ & & & & & & & & & $0.886^{* *}$ & $0.778 * *$ & 0.028 & $0.756^{*}$ \\
\hline HSWrp & & & & & & & & & 100000 & $0.975^{*}$ & $-0.754 * *$ & $0.572 * *$ \\
\hline $\mathrm{Rg}$ & & & & & & & & & & 0.274 & 0.018 & $0.392 * *$ \\
\hline AGBrp & & & & & & & & & & 100000 & $-0.687 *$ & 0.241 \\
\hline $\mathrm{Rg}$ & & & & & & & & & & & $0.689 * *$ & $0.698 * *$ \\
\hline HI rp & & & & & & & & & & & 100000 & $0.5293 * *$ \\
\hline $\mathrm{Rg}$ & & & & & & & & & & & & $0.467 * *$ \\
\hline PY & & & & & & & & & & & & 100000 \\
\hline
\end{tabular}

*and** significant at 0.05 and 0.01 respectively. 


\subsubsection{Phenotypic and Genotypic Correlation Among Other Character than Yield}

At Agarfa location on Table 9 phenotypic level correlation of number of days to emergence significant and positively correlated with days to flowering initiation, days to flowering. and highly significance and positive correlation with days to flowering at Goro site. Days to emergence had significant and positive correlation with pod length, 100 seed weight, above ground biomass at Goro. Days to emergence had highly significance and negative correlation with seed per pods at Agarfa location. Days to flower initiation had highly significantly and positively correlated days to flowering, pod per plant and days to maturity. Days to flower initiation had significantly and positively correlated pod length and plant height Days to flowering was highly significantly and positively correlated days to pod per plant, pod length and harvest index.

Days to flowering was significantly and positively correlated days to maturity. Number of pods per plant had highly significantly and positively correlated with seed per pods and 100 seed weight, whereas thousand seed weight significantly and positively correlated with seed yield per plot. This result indicates that as number of pods increase, seed yield per plot also increase. There was highly significant and positively correlated characters, positively and significantly correlated characters, and significant and negatively correlated character at each site. Days to flowering, days to maturity and days to flower initiation was significant and negatively correlated with number of pods per plant and hundred seed weight at both site. At phenotypic level, most of two site results were the same for the same character. This implies that environmental effect up on these characters is low which is similar with that [54].

Genotypic level of correlations of both sites, days to emergence was highly significantly and positively correlated with pod per plant. Whereas, days to flower initiation was highly significantly and positively correlated with days to flowering. Days to maturity had highly significantly and positively correlated with days to flower initiation. Seed per pod had highly significant and positively correlated with 100 seed weight, and aboveground biomass. These were characters which had highly significant and positively correlated, significant and positive correlated, significant and negative correlate, and highly significant and negatively correlated at each site.

At phenotypic and genotypic level, in the combined analysis for over two locations on Table 13 showed that, day to flower initiation, day to flowering and pod per plant was highly significant and positively correlated with days to emergence level. According to this study, day to flowering was also positively correlated with number seed per pod, pod length, plant height and pods per plant at both locations. Generally, the study of interrelations between character aims to improve variety must be set simultaneously. The interrelations reveal how the improvement of one character can cause alterations in others. Day to flower initiation and days to flowering was highly significantly and positively correlated with days to flowering and days to maturity respectively and whereas days to maturity had highly significant and positively correlated with plant height.

Plant height had significance and positively correlated with 100 seed weight. Thousand seed weight also had highly significance and negatively correlated with days to flower initiation and days to maturity. These results indicated that the greater the number of branches per plant, higher number of pods and number of seed per plant and thus ultimately contributing positively towards yield. These studies [55-56] reported similar findings of positive and significant correlation between number of seed per plant and number of pods per plan and plant height. Similar result were reported by a study [57] which conducted studies on 62 indigenous and exotic field pea genotypes and concluded that seed yield per plant showed highly significant and positive correlation with biological yield and harvest index. Days to maturity exhibited highly significant and positive correlations with number of pods/plant, number of seeds/pod and plant height. Biological yield/plant was also highly significant and positively correlated with plant height and number of seeds/plant.

Table 10. Phenotypic and genotypic correlation coefficients among 12 characters of 16 field pea phenotype studied at Goro, 2018.

\begin{tabular}{|c|c|c|c|c|c|c|c|c|c|c|c|c|}
\hline & DE & DI & DF & DM & PPP & SP & PL & $\mathbf{P H}$ & HSW & ABM & HI & PY \\
\hline DE rp & 10000 & 0.015 & $0.797 *$ & -0.266 & 0.078 & 0.207 & $0.379 * *$ & $-0.879 * *$ & 0.321 ** & $0.458^{* *}$ & 0.348 & $0.357 * *$ \\
\hline $\mathrm{Rg}$ & & $0.949 *$ & $0.674 * *$ & $0.579 * *$ & $0.669^{*}$ & $0.268^{* *}$ & $0.448^{* *}$ & 0.382 & 0.730 & 0.181 & $0.469 * *$ & $0.784 *$ \\
\hline DI rp & & 10000 & $0.757^{*}$ & $0.767 *$ & -0.458 & -0.282 & $0.247 * *$ & $0.698 * *$ & -0.632 & -0.136 & -0.097 & $0.086^{* *}$ \\
\hline $\mathrm{Rp}$ & & & $0.543 * *$ & 0.453 & $0.821^{*}$ & $0.999 *$ & 0.177 & $0.768^{*}$ & $0.526^{* *}$ & $0.469^{* *}$ & $0.599 * *$ & $0.687 * *$ \\
\hline DF rp & & & 10000 & $0.667 * *$ & $0.745^{*}$ & $0.584 * *$ & $0.904 *$ & 0.023 & -0.091 & -0.286 & $0.558^{* *}$ & 0.138 \\
\hline $\mathrm{Rg}$ & & & & $0.245^{* *}$ & $0.851^{*}$ & $0.492 * *$ & $0.624 * *$ & $0.979^{*}$ & $0.696^{* *}$ & 0.257 & $0.764 * *$ & $0.578^{*}$ \\
\hline DM rp & & & & 10000 & -0.147 & -0.195 & 0.134 & $0.388 * *$ & $0.497 *$ & -0.215 & 0.237 & -0.024 \\
\hline $\mathrm{Rg}$ & & & & & $0.458^{* *}$ & $0.956^{*}$ & $0.469 * *$ & 0.066 & $0.789 *$ & 0.269 & $0.903 *$ & $0.897^{*}$ \\
\hline PPP rp & & & & & 10000 & $0.978 *$ & -0.081 & $0.370 * *$ & 0.155 & -0.194 & 0.202 & $0.163^{*}$ \\
\hline $\mathrm{Rg}$ & & & & & & $0.384 * *$ & $0.964 *$ & 0.037 & $0.395^{* *}$ & $0.286^{* *}$ & 0.279 & $0.373 * *$ \\
\hline SP rp & & & & & & 10000 & $0.655^{* *}$ & 0.216 & 0.288 & $0.088^{* *}$ & 0.323 & $0.998 *$ \\
\hline $\mathrm{Rg}$ & & & & & & & $0.396^{* *}$ & $0.344 * *$ & 0.092 & 0.696 & 0.068 & $0.263^{*}$ \\
\hline PL rp & & & & & & & 10000 & $0.692 *$ & -0.272 & -0.186 & $0.878^{*}$ & $-0.373 * *$ \\
\hline $\mathrm{Rg}$ & & & & & & & & 0.136 & $0.316^{* *}$ & 0.306 & $0.988^{*}$ & $0.735 *$ \\
\hline
\end{tabular}




\begin{tabular}{|c|c|c|c|c|c|c|c|c|c|c|c|c|}
\hline & DE & DI & DF & DM & PPP & SP & PL & PH & HSW & ABM & HI & PY \\
\hline PH rp & & & & & & & & 10000 & 0.235 & $-0.474 * *$ & 0.396 & $0.675^{*}$ \\
\hline $\mathrm{Rg}$ & & & & & & & & & $0.507 * *$ & 0.216 & 0.026 & $0.336^{* *}$ \\
\hline HSWrp & & & & & & & & & 10000 & $0.397 * *$ & $0.378 * *$ & $0.293 * *$ \\
\hline $\mathrm{Rg}$ & & & & & & & & & & 0.025 & 0.037 & $0.129 * *$ \\
\hline ABMrp & & & & & & & & & & 10000 & -0.185 & 0.028 \\
\hline $\mathrm{Rg}$ & & & & & & & & & & & $0.468 * *$ & $0.878^{*}$ \\
\hline HI rp & & & & & & & & & & & 10000 & $0.657^{* *}$ \\
\hline $\mathrm{Rg}$ & & & & & & & & & & & & $-0.657 * *$ \\
\hline PYrp & & & & & & & & & & & & 10000 \\
\hline
\end{tabular}

*and** significant at 0.05 and 0.01 respectively.

Table 11. Combined analysis of Genotypic and phenotypic correlation coefficients among 12 characters of 16 Field pea genotype studded at Agarfa and Goro in 2019.

\begin{tabular}{|c|c|c|c|c|c|c|c|c|c|c|c|c|}
\hline & DE & DI & DF & DM & PPP & SP & PL & PH & HSW & ABM & HI & PY \\
\hline DE rp & 10000 & $-0.568^{*}$ & $-0.602^{*}$ & $0.598^{*}$ & $0.626^{*}$ & 0.207 & 0.103 & $0.565^{*}$ & $0.675^{*}$ & -0.119 & $0.648^{*}$ & $0.403 * *$ \\
\hline $\mathrm{Rg}$ & & 0.436 & $0.721 *$ & $0.543 * *$ & $0.923 * *$ & 0.108 & 0.417 & $0.683 * *$ & $0.832 * *$ & $0.3481 * *$ & 0.357 & $0.752 * *$ \\
\hline DI rp & & 10000 & $0.912^{*}$ & -0.355 & $-0.556^{*}$ & -0.261 & -0.101 & $-0.587 *$ & $-0.627 *$ & 0.118 & -0.637 & 0.127 \\
\hline $\mathrm{Rg}$ & & & $0.624 * *$ & 0.045 & $0.675^{* *}$ & 0.038 & $0.429^{* *}$ & $0.943^{*}$ & $0.643^{*}$ & $0.369 * *$ & $0.243^{* *}$ & $0.318^{* *}$ \\
\hline DF rp & & & 10000 & $-0.498^{*}$ & $-0.629^{*}$ & -0.199 & -0.193 & $-0.687^{*}$ & $0.712 *$ & 0.117 & 0.718 & 0.135 \\
\hline $\mathrm{Rg}$ & & & & $0.934 * *$ & $0.422^{* *}$ & 0.114 & 0.127 & $0.734^{* *}$ & $0.456^{* *}$ & $0.356^{* *}$ & $0.642 * *$ & $0.288^{*}$ \\
\hline DMrp & & & & 10000 & $0.658^{*}$ & 0.134 & $0.332^{* *}$ & $0.812^{*}$ & $0.645^{* *}$ & -0.354 & $0.719^{*}$ & -0.183 \\
\hline $\mathrm{Rg}$ & & & & & $0.246^{* *}$ & $0.296^{* *}$ & $0.672 *$ & $0.751 * *$ & $0.872^{*}$ & 0.041 & 0.321 ** & 0.158 \\
\hline PPPrp & & & & & 10000 & 0.145 & 0.199 & $0.789^{*}$ & $0.718^{*}$ & -0.175 & $-0.855^{*}$ & -0.156 \\
\hline $\mathrm{Rg}$ & & & & & & $0.343^{*}$ & 0.115 & $0.334^{* *}$ & $0.256^{* *}$ & 0.179 & $0.423 *$ & $0.233^{* *}$ \\
\hline SP rp & & & & & & 10000 & 0.379 & $0.238^{* *}$ & $0.163^{* *}$ & -0.195 & $0.247^{* *}$ & 0.065 \\
\hline $\mathrm{Rg}$ & & & & & & & $0.654 *$ & 0.068 & $0.208^{* *}$ & 0.122 & 0.049 & $0.609 *$ \\
\hline PL rp & & & & & & & 10000 & $0.378^{* *}$ & 0.134 & 0.237 & -0.294 & -0.365 \\
\hline $\mathrm{Rg}$ & & & & & & & & $0.921^{*}$ & $0.299^{* *}$ & $0.594 * *$ & 0.186 & $0.269^{* *}$ \\
\hline PH rp & & & & & & & & 10000 & $0.726^{*}$ & $0.736^{* *}$ & $0.853^{*}$ & $0.369 * *$ \\
\hline $\mathrm{Rg}$ & & & & & & & & & $0.832 *$ & $0.325^{* *}$ & $0.459 * *$ & $0.862 *$ \\
\hline HSWrp & & & & & & & & & 10000 & 0.135 & $0.565^{* *}$ & $0.778 *$ \\
\hline $\mathrm{Rg}$ & & & & & & & & & & $648^{*}$ & 0.429 & $0.789 *$ \\
\hline ABMrp & & & & & & & & & & 10000 & $0.718^{*}$ & $0.833^{*}$ \\
\hline $\mathrm{Rg}$ & & & & & & & & & & & 0.296 & $0.368^{* *}$ \\
\hline HI rp & & & & & & & & & & & 10000 & $0.645^{*}$ \\
\hline $\mathrm{Rg}$ & & & & & & & & & & & & $0.384 * *$ \\
\hline PYrp & & & & & & & & & & & & 10000 \\
\hline
\end{tabular}

*and** significant at 0.05 and 0.01 respectively.

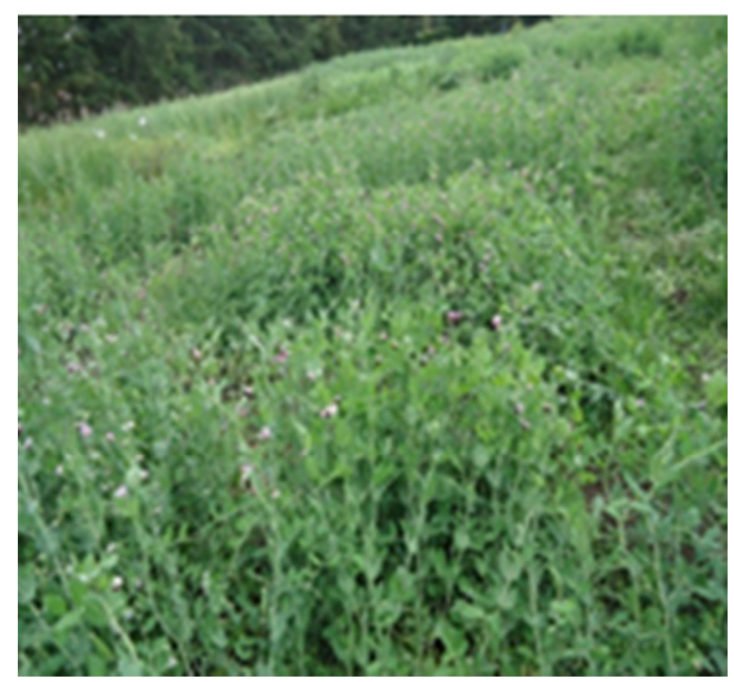

Figure 1. Flower initiation stage. 


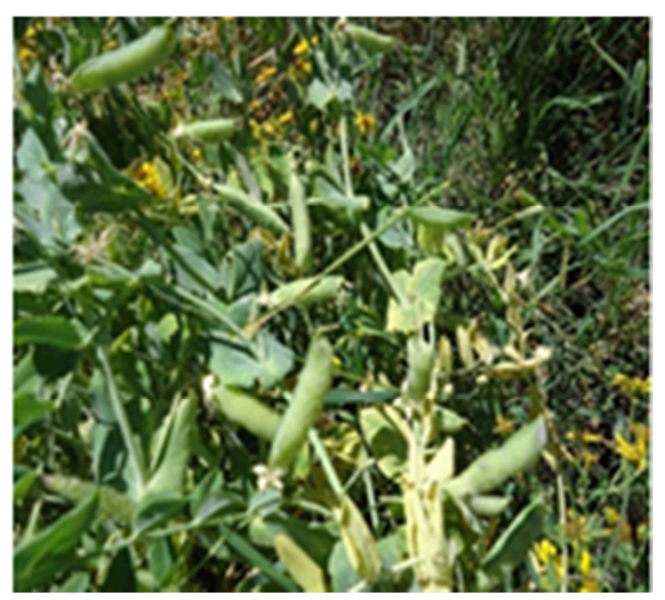

Figure 2. Maturity stage.

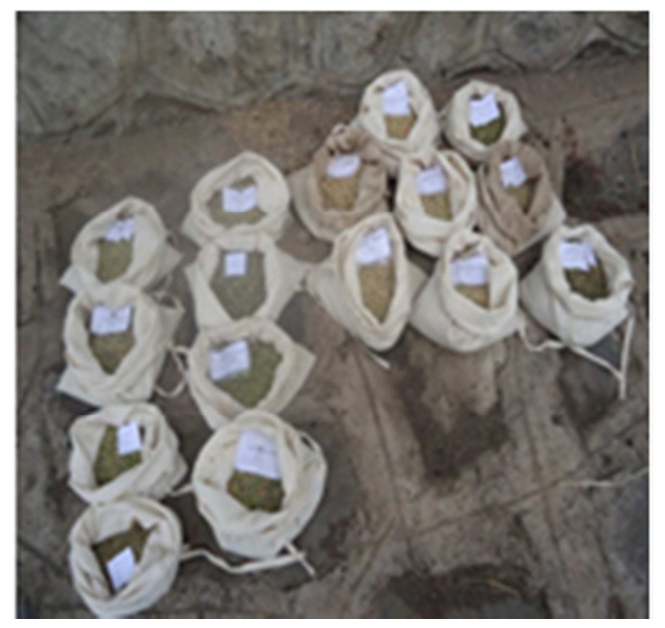

Figure 3. Varieties of field peas Seeds.

\subsection{Compare Average Yield Performance of Field Pea Farmer's Varieties in Contrast to Improved Varieties of by Using Compost}

Table 12. Average yield in kunt/hectar of Field pea farmer's varieties in contrast to improved varieties of by using compost at Agarfa location.

\begin{tabular}{llllll}
\hline No & Treatments & Average yield kunt/hect & No & Treatments & Average yield kunt/hect \\
\hline & Field peaFarmers varieties & & & Field pea Improved varieties & \\
1 & Orome & 28.13 & 1 & Wayib & 19.79 \\
2 & 32039 & 22.91 & 2 & Harana & 30.71 \\
3 & 231282 & 30.21 & 3 & Urji & 22.38 \\
4 & 231284 & 27.08 & 4 & Tulu shenan & 26.54 \\
5 & 230665 & 23.96 & 5 & Hortu & 25.0 \\
6 & 32038 & 30.83 & 6 & Bamo & 24.99 \\
7 & 320339 & 30.21 & 7 & Hursa & 27.58 \\
8 & 320337 & 27.08 & 8 & Wayitu & 20.83 \\
\hline
\end{tabular}

Table 13. Average yield in kunt/hectar of Field pea farmer's varieties in contrast to improved varieties of by using compost at Goro location.

\begin{tabular}{llllll}
\hline No & Treatments & Average yield kunt/hect & No & Treatments & Average yield kunt/hect \\
\hline & Field peaFarmers varieties & & & Field pea Improved varieties & \\
1 & 32038 & 14.58 & 1 & Harana & 8.34 \\
2 & 32039 & 18.75 & 2 & Bamo & 9.38 \\
3 & Orome & 9.38 & 3 & Hortu & 12.5 \\
4 & 320337 & 14.58 & 4 & Wayib & 9.38 \\
5 & 231284 & 16.67 & 5 & Tulu shenan & 10.42 \\
6 & 320339 & 12.49 & 6 & Hursa & 12.5 \\
7 & 231282 & 15.63 & 7 & Wayitu & 13.5 \\
8 & 230665 & 14.58 & 8 & Urji & 10.42 \\
\hline
\end{tabular}


As result indicated in Table 12 the highest seed yield was recorded in 32038 variety $(30.83 \mathrm{kunt} / \mathrm{hect}$ and the lowest seed yield was recorded in 32039 variety $(22.91 \mathrm{kunt} / \mathrm{hect})$ from farmers varieties, while Harana variety (30.71 kunt/hect) and Wayib variety (19.79 kunt/hect) the highest and lowest seed yield from improved varieties at Agarfalocation. In Goro (Table 13) indicated that the highest seed yield was recorded in 32039 variety $(18.75 \mathrm{kunt} /$ hect and the lowest seed yield was recorded in Orome variety $(9.38 \mathrm{kunt} / \mathrm{hect})$ from farmers varieties, while Wayitu variety (13.5 kunt/hect) and Harana variety $(8.34 \mathrm{kunt} / \mathrm{hect})$ the highest and lowest seed yield from improved varieties. This result contradicted the idea raised by some authors which show farmers varieties have low grain yield when compare with improved varieties. Yield per hectare of Abyssinian pea was predicted. The overall category indicated, the common yield in kilograms per hectare (100 kg ha-1) for Abyssinian pea is $300 \mathrm{~kg}$ ha-1 for most districts. Still the production is below the good average yield compared to green peas pods which is 6.5-7 MT ha-1[58]. This could be because of the small seed rate. Better seed rates can yield up to about $400 \mathrm{~kg}$ hal of Abyssinian pea. This seeks urgent intervention to fill yield gap [59]. Little productions were observed during the study period in some sporadic areas of Endamehoni lowlands, and Ofla and Gubalafto high land areas which are belg season productive [60].

\section{Summary, Conclusions and Recommendations}

Information on the extent and pattern of genetic variability in a population, interrelationship among different agronomic characters and knowledge of the naturally occurring diversity are essential to design breeding strategies in crop improvement. To generate such information in Field pea 16 genotypes ( 8 released varieties and 8 farmer's varieties) were obtained from Sinana Agricultural Research Center (SARC) and Biodiversity Conservation institute (BCI). A study was undertaken at two sites; Goro and Agarfa community seed bank site during the $2017 / 18$ main cropping season. The objectives were to estimate the genetic variability, heritability and genetic advance of different pea genotypes: to compare yield product performance selected landraces and released varieties of field pea genotypes and to assess the extent of association among agronomic characters of field pea genotypes.

The data generated from the experiment were subjected to analysis of variance, computation of genotypic and phenotypic coefficients of variations, estimations of heritability in broad sense, expected genetic advance, phenotypic and genotypic correlations and comparing yield performance of improved varieties with farmer's varieties by using compost. Results of analysis of variance showed statically significant difference among the tested genotypes for all the characters considered.
Both at Agarfa and Goro highly significant $(\mathrm{P}<0.01)$ genotypic difference were observed among the genotypes for all characters considered Table 6 and 7. The significance of genotype difference indicates the presence of variability for each of the characters among the tested entries.

After combined analysis, highly significant $(\mathrm{P}<0.01)$ location effect for days to emergence, days to flowering, days to flower initiation, days to maturity, number of pod per plant, plant height, yield per plot while 100 seed weight, seed per pod and pod length had significant location effect indicating the phenotypic expression of these characters were different at the two locations Table 7. Genotype effects was highly significant for days to maturity while the rest were significant for all traits except above ground biomass and Harvest index. The Mean square due to genotype (G) $x$ location (L) interaction was highly significant for days to maturity and days to flowering initiation and days to flowering while pod per plant, pod length, seed per pod, yield per plot,100 seed weight and plant height significant, this indicate that differential response of genotypes for these character at each location.

At Agarfa, the highest genetic variance were observed for harvest index (8690.46) and plant height (615.96). While lowest genotypic variance were found for seed per pod $(0.25)$, days to emergence $(0.375)$, pod length $(0.445)$ above ground biomass (0.77).

At Goro, all the 12 characters studied showed a phenotypic variance greater than the genotypic variance (Table 9). At Goro, the genotypic variance is smaller than that of environmental variance except for days to emergence $(0.37)$ days to flower initiation (56.2) and days to maturity (47.07) and in combined analysis, genotypic variances were higher than their environmental for all characters. This indicates that in the phenotypic variance the contribution of genotypic variance was high for all characters.

At Agarfa, the highest PCV was observed for harvest index (77.07\%), number of pods per plant (35.54\%), above ground biomass (36.7\%), and seed yield per plant (30.9\%). The estimated PCV was low for days to emergence (7.3\%), days to maturity (6.4\%) and seed yield per pod (8.3). High genotypic coefficient of variation (32.52\%) and (32.07\%) were observed for Harvest index and number of seeds per pod, respectively. Whereas, the lowest value of genotypic coefficient of variation was estimated for days to maturity $(0.24 \%)$. Likewise phenotypic coefficient of variation was high for the number of seeds per pod (241.13\%) followed by $(173.59 \%)$.

In Agarfa low GCV were observed for days to emergence (5.8), days to flower initiation (6.86), days to maturity (6.05), seed per pods (6.65) and 100seed weight (8.84) while highest GCV was recorded for harvest index (69.4).

At Goro, the highest GCV was recorded for days to flower $(62.0 \%)$ whereas the moderate genotypic coefficient variances (GCV) were found for seed yield per plot (19\%), above ground biomass $(11.8 \%)$ and days to flower initiation (10.8\%). However, the lowest GCV were recorded for seed per pod (1.2\%) and 100 seed weight (3.3\%). The phenotypic 
coefficient variances (PCV) were found for days to flowering (95\%), harvest index $(39.6 \%)$, above ground biomass $(36.6 \%)$, seed yield per plot $(26.6 \%)$, pods number per plant (26\%), plant height (17\%) 100 seed weight (13\%) and days to flower initiation $(13 \%)$ while lowest PCV recorded seed per pods $(8.4 \%)$, pod length $(9.6 \%)$, days to emergence $(9.6 \%)$, days to maturity $(6.6 \%)$.

Generally classified heritability estimates as low $(<50 \%)$, medium $(50-70 \%)$ and high $(>70 \%)$. Based on this classification, at Agarfa the characters that had get highest heritability values are pod length $(87.2 \%)$, days to maturity (88.9) while seed per pods (63.2\%) Plant height (62.2) and day to flowering $(68.7 \%)$, pod per plant $(57.5 \%)$, harvest index $(53.5 \%)$ had medium heritability. However, seed yield per pod (39.6\%), days to flower initiation $(38.8 \%)$ and above ground biomass $(47.2 \%)$ and had low heritability values.

At Goro, the highest heritability values was recorded by days to maturity $(87 \%)$ and day to flower initiation $(70 \%)$ whereas, yield per plot $(52 \%)$, days to emergence $(63 \%)$ recorded medium results. Day to flowering (43\%) and the rest of characters were recorded low heritability. The lowest heritability was recorded by seed per pods $(2.1 \%)$.

At Agarfa, genetic advance ranged from (7.8\%) for days $\mathrm{f}$ flower initiation to, (167.7\%) harvest index. There was relatively high genetic advance expressed as percentage of Mean for characters numbers of pods per plant, seed yield per plot, thousand seed weight, number of pods per plant and above ground biomass. At Goro, the range for genetic advance as present Mean was from $1.7 \%$ for pod per plant to $98 \%$ for days to flowering Table 9 . The rest had relatively medium and low genetic advance expressed as percentage of Mean.

Phenotypic (rp) and Genotypic (rg) correlation estimates between the various characters are presented for Goro, Agarfa and combined respectively. At genotypic level, plant height, days to flower initiation, pod per plant and pod length at Agarfa and days to emergence, days to flowering, number of pods per plant, pod length and above ground biomass at Goro had highly significantly and positively correlated with seed yield per plot.

At both locations, phenotypic level of seed yield per plot was highly significantly and positively correlated with pods per plant, seed per pod and plant height. seed weight (rp = $0.126)$ and seed yield per plant $\left(\mathrm{rp}=0.103^{* *}\right)$ while, biological yield per plot $\left(\mathrm{rp}=0.185^{*}\right)$ and harvest index $(\mathrm{rp}=0.1220 \mathrm{had}$ significant and positive correlation with grain yield per plot.

Genotypic level of correlations of both sites, days to emergence was highly significantly and positively correlated with pod per plant. Whereas, days to flower initiation was highly significantly and positively correlated with days to flowering. Days to maturity had highly significantly and positively correlated with days to flower initiation. Seed per pod had highly significant and positively correlated with 100 seed weight, and aboveground biomass.

The highest seed yield was recorded in 32038 variety (30.83kunt/hect and the lowest seed yield was recorded in 32039 variety $(22.91 \mathrm{kunt} / \mathrm{hect})$ from farmers varieties, while Harana variety $(30.71 \mathrm{kunt} / \mathrm{hect})$ and Wayib variety (19.79 kunt/hect) the highest and lowest seed yield from improved varieties at Agarfa location.

In Goro (Table 13) indicated that the highest seed yield was recorded in 32039 variety $(18.75 \mathrm{kunt} /$ hect and the lowest seed yield was recorded in Orome variety $(9.38 \mathrm{kunt} / \mathrm{hect})$ from farmers varieties, while Wayitu variety (13.5 kunt/hect) and Harana variety ( $8.34 \mathrm{kunt} / \mathrm{hect})$ the highest and lowest seed yield from improved varieties.

The study revealed out, new landrace which had high yield as released variety and variety which need improvement. Carried out at two site helped researcher to get more realistic result and identified which character affect regardless of environmental effect on the yield. Combined analysis agree the location wise result that means genotypic by environmental interaction variation is more significant.

\section{Appendix}

Table A1. Mean values of 12 characters of 16 Field pea genotypes grown at Agarfa.

\begin{tabular}{|c|c|c|c|c|c|c|c|c|c|c|c|c|}
\hline No. & EM & FI & FLO & MAT & PP & SP & PL & $\mathbf{P H}$ & PY & HGW & AGB & HI \\
\hline Wayib & 9.0 & 53 & 58 & 128 & 31.0 & 6.6 & 6.0 & 208 & 1.3 & 16 & 2.6 & 50.0 \\
\hline Harana & 9.0 & 53 & 58 & 132 & 35.0 & 5.6 & 5.6 & 198 & 1.5 & 18 & 2.7 & 55.5 \\
\hline Urji & 9.0 & 52 & 59 & 132 & 33.2 & 6.0 & 6.0 & 183 & 1.5 & 17 & 3.5 & 42.5 \\
\hline Tulu shenan & 10 & 56 & 60 & 128 & 31.0 & 5.6 & 5.6 & 183 & 1.0 & 15 & 3.0 & 33.3 \\
\hline Hortu & 10 & 58 & 64 & 132 & 33.4 & 5.8 & 6.0 & 210 & 1.2 & 14 & 4.0 & 30.0 \\
\hline Bamo & 10 & 60 & 65 & 132 & 45.0 & 5.6 & 5.4 & 186 & 1.4 & 16 & 4.2 & 33.3 \\
\hline Hursa & 9.0 & 64 & 62 & 134 & 46.0 & 5.0 & 5.6 & 160 & 1.5 & 18 & 4.0 & 37.5 \\
\hline Wayitu & 10 & 52 & 60 & 134 & 60.6 & 4.8 & 5.0 & 177 & 1.1 & 16 & 4.0 & 27.5 \\
\hline Orome & 11 & 58 & 65 & 110 & 29.2 & 5.2 & 5.4 & 118 & 1.6 & 18 & 4.2 & 38.1 \\
\hline 32039 & 10 & 58 & 65 & 132 & 52.0 & 5.8 & 5.6 & 168 & 1.1 & 17 & 3.8 & 28.9 \\
\hline 231282 & 12 & 60 & 67 & 132 & 38.8 & 5.6 & 5.6 & 138 & 1.8 & 16 & 2.6 & 69.2 \\
\hline 231284 & 12 & 52 & 60 & 128 & 57.6 & 5.2 & 5.6 & 142 & 1.2 & 21 & 2.8 & 42.8 \\
\hline 230665 & 11 & 53 & 60 & 128 & 37.8 & 5.6 & 5.6 & 139 & 1.1 & 18 & 2.5 & 44.0 \\
\hline 32038 & 11 & 58 & 67 & 128 & 31.8 & 5.6 & 5.4 & 119 & 1.4 & 13 & 1.8 & 77.8 \\
\hline 320339 & 12 & 59 & 67 & 130 & 39.0 & 6.2 & 5.4 & 160 & 1.3 & 14 & 3.2 & 40.6 \\
\hline
\end{tabular}




\begin{tabular}{|c|c|c|c|c|c|c|c|c|c|c|c|c|}
\hline No. & EM & FI & FLO & MAT & PP & SP & PL & PH & PY & HGW & AGB & HI \\
\hline 320337 & 12 & 46 & 52 & 132 & 27.2 & 5.4 & 5.8 & 140 & 1.2 & 18 & 3.4 & 35.2 \\
\hline Mean & 10.4 & 53.3 & 60.21 & 129.9 & 38.68 & 6.01 & 5.78 & 156.7 & 1.25 & 16.43 & 3.48 & 37.84 \\
\hline $\mathrm{CV}$ & 10.06 & 8.66 & 9.05 & 2.13 & 24.76 & 6.7 & 4.55 & 12.34 & 22.09 & 11.16 & 26.6 & 33.38 \\
\hline $\operatorname{LSD}(5 \%)$ & 0.78 & 3.48 & 4.1 & 2.09 & 7.21 & 0.3 & 0.91 & 14.5 & 1.38 & 0.2 & 0.69 & 9.5 \\
\hline
\end{tabular}

Table A2. Mean values of 12 characters of 16 Filed pea genotypes grown at Goro.

\begin{tabular}{|c|c|c|c|c|c|c|c|c|c|c|c|c|}
\hline No. & EM & FI & FLO & MAT & PP & SP & PL & PH & PY & HGW & AGB & HI \\
\hline Harana & 7 & 74 & 88 & 119 & 8.20 & 5.2 & 5.8 & 78.0 & 0.4 & 17 & 1.3 & 30.7 \\
\hline Bamo & 7 & 71 & 81 & 119 & 10.2 & 6.0 & 6.6 & 92.6 & 0.5 & 20 & 1.0 & 0.50 \\
\hline Hortu & 7 & 73 & 79 & 112 & 17.8 & 5.6 & 6.4 & 100.4 & 0.6 & 15 & 1.7 & 35.2 \\
\hline Wayib & 7 & 69 & 76 & 112 & 21.4 & 6.0 & 6.4 & 106.8 & 0.5 & 14 & 1.7 & 29.4 \\
\hline Tulu shenan & 7 & 69 & 76 & 112 & 20.4 & 4.2 & 5.6 & 91.6 & 0.4 & 18 & 1.7 & 3.50 \\
\hline Hursa & 7 & 67 & 74 & 116 & 21.6 & 6.4 & 6.2 & 122 & 0.5 & 14 & 1.7 & 29.4 \\
\hline Wayitu & 7 & 65 & 73 & 116 & 23.4 & 5.0 & 5.2 & 128 & 0.7 & 16 & 1.2 & 58.3 \\
\hline Urji & 7 & 79 & 69 & 119 & 12.2 & 5.6 & 5.4 & 73.0 & 0.6 & 18 & 1.0 & 60.0 \\
\hline 32038 & 7 & 66 & 79 & 112 & 17.0 & 5.0 & 5.4 & 77.0 & 0.7 & 20 & 1.0 & 0.70 \\
\hline 32039 & 8 & 65 & 81 & 110 & 16.6 & 6.4 & 5.4 & 106 & 1.0 & 18 & 2.0 & 50.0 \\
\hline Orome & 8 & 44 & 50 & 88.0 & 15.8 & 5.0 & 5.6 & 87.0 & 0.5 & 21 & 1.0 & 20.0 \\
\hline 320337 & 8 & 69 & 79 & 119 & 19.0 & 6.2 & 5.0 & 113 & 0.8 & 17 & 2.0 & 40.0 \\
\hline 231284 & 8 & 44 & 70 & 110 & 18.4 & 6.2 & 4.8 & 102 & 0.8 & 19 & 1.5 & 53.3 \\
\hline 320339 & 8 & 72 & 81 & 110 & 30.2 & 6.4 & 5.8 & 102 & 0.5 & 16 & 1.5 & 33.3 \\
\hline 231282 & 8 & 67 & 77 & 108 & 34.8 & 6.0 & 6.0 & 110 & 0.7 & 18 & 1.5 & 46.6 \\
\hline 230665 & 8 & 73 & 79 & 108 & 22.6 & 6.0 & 5.4 & 76.2 & 0.8 & 20 & 1.5 & 53.3 \\
\hline Mean & 8.03 & 68.9 & 71.2 & 111.6 & 18.8 & 5.75 & 5.5 & 91.8 & 0.6 & 17.8 & 1.34 & 41.8 \\
\hline $\mathrm{CV}$ & 5.76 & 7.05 & 6.45 & 2.36 & 25.4 & 8.38 & 7.9 & 15.78 & 18.8 & 12.5 & 13.3 & 38.8 \\
\hline LSD (5\%) & 0.34 & 3.81 & 3.81 & 1.98 & 3.61 & 0.36 & 0.32 & 10.9 & 0.08 & 1.67 & 0.33 & 12.2 \\
\hline
\end{tabular}

\section{References}

[1] Abhishek et al., 2015 Characterization and Evaluation of Field Pea Genotypes for Yield and Quality Attributing Traits. Jawaharlal Nehru Krishi Vishwa Vidyalaya, Jabalpur Msc Thesis.

[2] Allard, R. W, 1996. Principles of plant breeding, John wilky and sores inc, New York.

[3] Basaiwala P. 2006. Genetic analysis of seed yield and seed parameters in field pe (Pisumsativum L.). M.Sc. (Ag.) Thesis, IGKV, Raipur. 42p.

[4] Blen Wondimageghu 2017. Phenotypic Diversity and Mineral Contents of Field Pea (Pisumsativum L) Accessions from North Wollo and South Tigray, and Improved/ Introduction Varieties. Addis Ababa University, June 2017.

[5] Benti Ofga'a Jaleta (2014). Genetic variability and association among agronomic characters in selected field pea (Pisumsativum L.) genotypes at Bale zone, Sinana Research Center, Oromia region, Ethiopia. MSc Thesis, Haramaya University. Haramaya, Ethiopia. pp 55.

[6] Berhane G. et al., 2018. Evaluation of farmers' knowledge on the rare Abyssinian pea (Pisumsativum var. abyssinicum) landraces of Ethiopia. Department of Biology, College of Science, Bahir Dar University. P.O. Box 76, Bahir Dar, Ethiopia.

[7] Burton. G. W, 1952. Quantitative inheritance in grasses. Proceediology of the 6th international grass congress 1 : 277-283.

[8] CSA, 2011. Agricultural Sample Survey 2010/11 (2003 EC).
Report on Area and Production of Crops Private Peasant Holdings, Meher Season. Addis Ababa. vol. I.

[9] CSA, 2012). Crop production forecast sample survey. Report on area and production for major crops private peasant holdings, meher season. Addis Ababa, Ethiopia.

[10] FAO, 1998. The State of World's Plant Genetic Resources for Food and Agriculture. Food and Agriculture Organization, Rome, Italy.

[11] Girma, B., 2003. The state of grain marketing in Ethiopia. Proceedings of the EDRI/IFPRI, 2020 Network Policy Forum on Toward Sustainable Food Security in Ethiopia: Integrating the Agri-Food Chain, May 15-16, 2003, Addis Ababa, Ethiopia Gilbert, Z. Gardening in South Africa, C. Struik, Cape Town, 1983.

[12] ICARDA, 2011. International Center for Agricultural Research in Dry Areas, Aleppo, Syria.

[13] Johnson, H, W., H, F. Robinson and R. E Comstock 1955 Estimates of genetic and environmental variability in soy beans. Agronomy Journal, Society: 126-131.

[14] Khan, T. N. Ramzan., A. Jillani., G. Mehamood. T, 2013. Morphological performance of peas (Pisumsativum L.) Genotypes under Rain fed conditions of Potowar Region. J. Agric, Res., 51 (10): 51-60.

[15] Lakić Ž., Stanković S., Pavlović S., Krnjajić S., Popović V. (2018): Genetic variability in quantitative traits of field pea (Pisumsativum L.) genotypes. Czech J. Genet. Plant Breed.

[16] Ministry of Agriculture and Rural Development (MoARD), 2010. Ministry of agriculture and rural development crop development department, crop variety register. Issue No. 19. 
[17] Mulusew, F., Tadele. T., Setegn. G., Bekele. H., 2010. Agronomic performance, disease reaction and yield stability of field pea (Pisumsativum L.) under South Eastern Ethiopian Conditions. Austraalian Journal Crops sciencces 4 (4): 238246.

[18] Mussa Jarso, Tezera Wolabu and Gemechu Keneni, 2006. Review of field pea (Pisumsativum L.) genetics and breeding research in Ethiopia. pp. 67-85.

[19] Nassef DMT. and El-Rawy MA. 2013. Analysis of gene effects controlling some traits in garden pea (Pisumsativum L.) Austrelian Journal of Basic Applied Science. 7 (1): 537-542.

[20] Pesta, A., Titlow, A., Hansen, J., Berger, A., Furman, S., Luebbe, M., Erickson, G. and Jenkins, K. (2012). Effects of feeding field peas in combination with distiller grains plus soluble in finishing and growing diets on cattle performance and carcass characteristics. The Professional Animal Scientist 28 (5): 534-540.

[21] Seboka Habtamuet al., 2013. Multivariate analysis of some Ethiopian field pea (Pisumsativum L.) genotypes. School of Plant Sciences, Haramaya University, P. O. Box 138, Dire Dawa, Ethiopia.

[22] Singh A. Singh S. BabuJDP. (2011) Heritability, character association and path analysis studies in early segregating population of field pea (Pisumsativum L. var. arvense). International Journal of Plant Breeding and Genetics. 5 (1): 86-92.

[23] Sharma, V. K. and Bora, L. 2013. Studies on genetic variability and heterosis in vegetable pea (Pisumsativum L.) under high hills condition of Uttarakhand, India. African Journal of Agriculture Research, 8 (18): 1891-1895.

[24] Temene $\mathrm{T}$ et al., 2013Genotype $\times$ Environment Interaction and Performance Stability for Grain Yield in Field Pea (Pisumsativum L.) Genotypes. Kulumsa Agricultural Research Center, P.O. Box 489, Asella, Ethiopia.

[25] Wani G, Mir B, Shah M. Evaluation of diversity in pea (Pisumsativum L.) genotypes using agro-morphological characters and RAPD analysis. Int. J Curr. Res. Rev. 2013; 5 (10): 17-25.

[26] Wright, S. 1921. Correlation and causation. Journal Agricultural Research. 20: 557-585.

[27] Yadav R. ShrivastavaRK. Ramakant and Singh R. (2009). Studies on genetic divergence in field pea (Pisumsativum L.) Legume Research, 32 (2): 121-124. 